Paper received: August $5^{\text {th }} 2015$

Paper accepted: October $7^{\text {th }} 2015$

Jelena Radišić ${ }^{,}, \mathrm{PhD}$

Institute for Educational Research, Belgrade, Serbia

Original Paper

Smiljana Jošić ${ }^{2}$, MA

Institute for Educational Research, Belgrade, Serbia

DOI:10.5937/inovacije1503099R

\title{
Challenges, obstacles and outcomes of applying inquiry method in primary school mathematics: example of an experienced teacher
}

\begin{abstract}
This paper analyses the attempts of an experienced mathematics teacher to apply principles of inquiry based teaching in her practice upon receiving training on the topic. Results of the analysis of teacher's practices based on her reflective accounts, lesson plan forms and observations of videotaped lessons show that the teacher devotes very little time to non-instructional activities, while instructional ones are in line with activities presumed to be part of the inquiry approach. With respect to the particular Components of Inquiry difference between the two observed lessons was found for the Explain phase of the lesson, although both Explore and Explain phases were consistently coded as higher level order (e.g. students were focused on problem solving, combining and constructing new ideas). The process was also followed by appropriate discursive patterns. Results are discussed in the light of the training received and possible improvements to be made.
\end{abstract}

Key words: mathematics, inquiry based learning, teacher.

\section{Introduction}

For the past two decades, there has been a clear push toward instructional practices that facilitate the active role of students in the process of learning along with their critical, deep order and divergent thinking. Although the model of inquiry essentially refers to science education (Rocard, Csermely, Jorde, Lenzen, Walberg-Henriksson \& Hemmo, 2007) extensive efforts have been made to develop and confer inquiry to the mathematics domain (Ar-

1 jradisic@ipi.ac.rs

2 sjosic@ipi.ac.rs tigue \& Baptist, 2012). As to mathematics per se it has been acknowledged that for students to excel in the world nowadays they must be equipped to solve complex problems instead of just memorizing algorithms, definitions and directly applying knowledge that was gained (Friedman, 2005). The same notion is supported by Programme for International Student Assessment (PISA) and Trends in International Mathematics and Science Study (TIMSS) data. Despite the fact our students obtain higher than average results in the latter these also suggest our students struggling the most when it comes to those tasks that acquire thinking outside-of-the-box 
(Gašić-Pavišić \& Stanković, 2012; Pavlović-Babić \& Baucal, 2013).

The focus of the present study is to examine inquiry practices in mathematics of one experienced teacher in an urban school setting. We intend to explore whether the amount of time spent on various components of inquiry, the order that these components are presented to students and discursive patterns behind it can relate to the cognitive level at which students are expected to work and learn. The teacher's reflective accounts will also be taken into account, as to assess the way teachers perceives own practice in an attempt to apply the inquiry method.

\section{Theoretical background}

In one form or another learning always involves knowledge construction irrespective of the domain in which is taking place. Thus it is of the essence to explore which kind of instructional practices are likely to promote such knowledge construction. When one observes mathematics as a domain, often mathematics is perceived as a set of formulae to be applied to a list of problems. Such a "misconception" is largely developed thanks to the way in which mathematics is often taught (i.e. teacher demonstrating a method of calculation and students subsequently repeating it without reflection) (Artigue \& Baptist, 2012). It is not surprising that for the past two decades we have been dealing with deliberative attempts to introduce more active teaching and learning methods in mathematics, along with a clear understanding of what makes some teachers more effective in introducing such practices than the others.

Inquiry based teaching in mathematics is among those approaches that focus on providing students with an active setting in which they are no longer passive recipients and consumers of knowledge. Rather, with the help of the teacher, they learn how to understand the concepts of mathematics, and not the mere mechanics of how to solve a cer- tain problem. The teacher is there to provide each student with essential scaffolding based on the students' interest, readiness and ability, while students question, explore, observe, discover, assume, explain, and prove mathematical concepts, which forces them to think critically and analytically in the realm of mathematics (Tomlinson \& McTighe, 2003). In Cobb's description of inquiry in mathematics, the classroom ideal would be the one positioning the teacher and students "acting in and elaborating a taken-as-shared mathematical reality in the course of their ongoing negotiations of mathematical meanings" (Cobb \& Yackel, 1998, p. 163).

At the same time, inquiry based teaching does resonate with the values elicited in the problem-solving tradition (Polya, 1945), the Realistic Mathematics Education (Freudenthal, 1973), the Theory of Didactical Situations (Brousseau, 1997), the socio-cultural approaches and the idea of community of practice (Lave \& Wenger, 1991) or the dialogical perspective (Bakhtin, 1981). To a certain degree, each of these approaches to mathematics education has something in common with the inquiry-based perspective, but each tends to shape its proposed values in its own particular way (Artigue, Dilon, Harlen \& Lena, 2012).

Inquiry as a pedagogy is primarily associated with John Dewey (Dewey, 1938). In his opinion inquiry as a method offers the possibility for the everyday experiences to reinforce students' natural thinking, rather than attempting to restructure thinking on the basis of subject-specific knowledge. In his understanding, inquiry naturally happens in the context of 'ordinary-life experiences', whilst subject knowledge serves only as a site for forming inquiry skills. However 'school context' inquiry is not necessarily like this. It does not have to start with everyday experiences. In mathematics, for example, a spur to inquiry can be a mathematical statement or an equation. If it is set just above the current knowledge of students, it can spark interest and questioning and encourage them to rise above themselves. 
Although students are in such a case somehow displaced from their own comfort zones and 'provoked' in a Piagetian manner (Piaget, 1969; Piaget \& Inhelder, 1978), it also allows them to perform in the zone where they can be challenged to think critically without being overwhelmed (Vygotsky, 1978). Scaffolding, one of the key elements of inquiry based learning, makes the learning more manageable for students by altering difficult and complex tasks in modes that make these tasks accessible, within the student's zone of proximal development (Vygotsky, 1978; Rogoff, 1990). Simultaneously an important feature of scaffolding is that it supports students' learning of both how to do the task, as well as why the task should be done following particular procedures. The latter is sometimes of key importance precisely for the domain of mathematics (HmeloSilver, 2006). Again irrespective of the domain, scaffolding facilitates problematizing important aspects of students' work in order to force them to engage with key disciplinary frameworks and strategies (Reiser, 2004).

The findings of several studies indicate that the application of an inquiry based approach in teaching has a positive impact on student achievement and motivation (e.g. GLEF, 2001; Hmelo-Silver, Duncan \& Chinn, 2007). The method is also found to contribute to the development of creativity and independence of students as they become directly responsible for the outcome at the end of the process (Kühne, 1995). This equally applies to those students who need additional support in their daily classroom activities. Over the last couple of years, several large European projects were aiming to promote inquiry-based learning in mathematics classes (e.g. the Fibonacci project, PRIMAS - Promoting Inquiry in Mathematics and Science Education). As some of the survey reports indicate, inquiry-based learning has not found its way into daily teaching practice (PRIMAS, 2011). Teachers' doubts about inquiry relate to several issues such as the fact that inquiry, with its focus on everyday experiences and inductive learning, is not envisioned as a genuine pedagogy for mathematics and some classroom level restraints on inquiry are commonly found (i.e. curriculum boundaries, students' lack of skills, classroom management issues).

However, in order for the meaningful inquiry to take place and to bring students investigations to a point of deep understanding regarding a key concept in the discipline, teachers need to be equipped to facilitate such investigations and to be able to analyse how to shape own practice in future inquiry endeavours.

Only a particular instructional move will help students to analyse instead of recall, to justify as an alternative to define, and to formulate instead of listing. In line with this, researchers and teacher trainers have developed theory-driven and empirically based design strategies for integrating effective scaffolding strategies to inquiry based learning (Hmelo-Silver, 2006; Quintana, Reiser, Davis, Krajcik, Fretz, Duncan, Kuza, Edelson \& Soloway, 2004; Reiser, Tabak, Sandoval, Smith, Steinmuller, \& Leone, 2001); yet in-service programs designed for disseminating inquiry-based teaching have been evaluated as producing varying results with regard to teachers' effective practices and further professional development (Nelson, 2009). Oliveira (2010) states how many short-term professional development programs provide incomplete information and fail to facilitate teachers' deeper understanding of classroom inquiries at the level originally intended. Oliveira further stresses the dynamic view of classroom inquiries and the need to take into account prior beliefs and practices of each teacher involved in such programmes along with their reflections on the process.

Most currently-used inquiry instructional models use a four component model (Eisenkraft, 2003; Bybee, Taylor, Gardner, Scotter, Powell, Westbrook \& Landes, 2006; Marshall et al., 2009; Marshal \& Horton, 2011), including: the engage phase (i.e. misconceptions and prior knowledge are exposed); the explore phase (i.e. learners actively investigate 
scientific concepts); the explain phase (i.e. prior knowledge is combined with the ongoing learning process as to generate conceptual understanding); and the extend phase (i.e. learning is deepened and applied to new situations), often observed as an addition of the engaging and exploring stages. During all of these phases, students are expected to actively engage and make sense of the data they have gathered. The teacher is there to probe, question, and help draw the pieces together. Having in mind this framework, we intend to answer the following questions: (1) how does the order of instruction narrate to the time spent to explore and explain the components of the inquiry process? (2) how does the order of instruction organized by the teacher relate to the cognitive level displayed by students? "explain" and "explore" phases will be central to our inquiry. and (3) which discursive patterns are played during the "explain" stage performed by the students? All questions will be observed from the stand point of teacher practices and how these are shaped as to address the needs of students.

\section{Methodology}

The paper is part of a five year project titled "From stimulating initiative, cooperation and creation in education to new roles and identities in society"3, realized by the Institute for Educational research. The project is taking place in an elementary school in Belgrade (Serbia) where a new model of teaching and learning has been implemented by focusing on promotion and fostering creativity, initiative and cooperation in the classroom. The so called "Trefoil" platform has been thoroughly described in several publications (Šefer \& Ševkušić, 2012; Šefer \& Radišić, 2012; Komlenović \& Šefer, 2013; Šefer, Stanković, Đerić \& Džinović, 2015).

As part of the third year of the Project, the entire teaching staff in the above-mentioned school

3 Grant number 179034, Ministry of Education, Science and Technological Development received one year of training covering topics related to fostering creativity, cooperation and initiative in the classroom. After each instructional session, the teachers had two weeks to apply the concepts after which these were discussed in focus groups gathering teachers of the same subject. As part of the follow up activities, each teacher prepared a lesson plan with reflections on how he/she perceived the activities during the lesson. Some of the performed lessons were also videotaped upon receiving an approval by the teacher. Prior to implementation of training sessions, two lessons of all the school teaching staff were observed by two researchers.

\section{Sample}

The current research is a case study on practices of one experienced mathematics teacher and her attempts to apply inquiry based teaching in the two classes she was teaching. Both classes included $6^{\text {th }}$ grade students (aged 12-13) and are taught the topic of congruence of triangles. In teacher's accounts both classes are typical $(\mathrm{N}=20)$ with one distinction that in one of them she is the class teacher.

\section{Lesson plan}

The teacher's lesson plan indicates the activities to be performed in groups. Each group received prompts as indicated below. The groups are heterogeneous with respect to school performance, composed of 3-4 students.. At the beginning of the lesson the teacher planned to use a Power Point presentation to introduce the topic, to give instruction to each group and to follow their work. The instruction for the students was to find as many ways possible to construct the same triangle as in the prompt they received. Each group has to check whether the constructed triangle is compatible to the original one. Each group has to present their own work and to discuss the solution, as well as the difficulties they had to overcome in the process. Criteria for ranking the group work included accuracy of the solution, the number of triangles constructed in differ- 
ent ways, the active participation of all students the level of cooperation on the basis of monitoring activities. The highest rank mistake was considered to be construction of a triangle, which is not compatible with the one given in the prompt.

\section{Figure 1. Example of a teacher prompt}

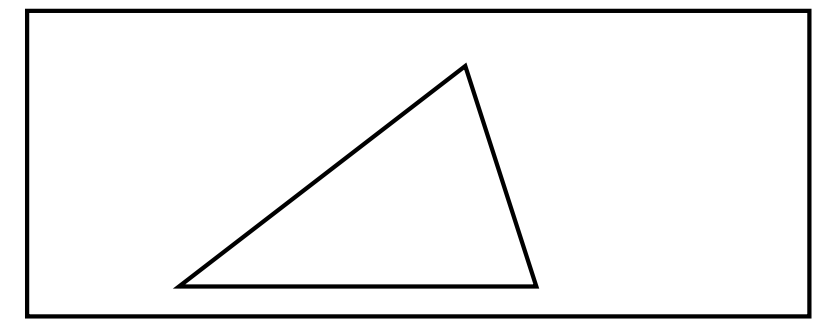

The teacher also needed to provide the researchers with a short narrative on her perception of both lessons, what she considered to be exceptionally good, what kind of difficulties she encountered, and whether the lesson realization differed with reference to the initial lesson plan.

\section{Videotaping procedures}

Two lessons were videotaped, one per class. In both classes, the teacher applied the same teaching unit. In this way we were able to capture the teacher's practices and to record possible differences with respect to the provided instruction. Recording was done using two cameras inside the classroom. One camera followed the teacher, while the other followed the interaction among students within the classroom. Ethical guidelines were fully followed during the recording and for each child parents' consents were obtained. After the videotaping was conducted, a semi-structured "post lesson video stimulated interview" was planned with the teacher, but due to technical difficulties (i.e. teacher's unavailability) these data are not available.

\section{Instrument}

Both classroom recordings were observed using the Electronic Quality of Inquiry Protocol (EQUIP; Marshall, Horton, Smart, \& Llewellyn,

Figure 2. Inquiry and Student Thinking - Part of a descriptive section describing order of instruction

\begin{tabular}{|c|c|c|c|c|c|}
\hline $\begin{array}{l}\text { Construct } \\
\text { measured }\end{array}$ & $\begin{array}{c}\text { Non-instructional } \\
\text { time } \\
\text { (Level 0) }\end{array}$ & $\begin{array}{l}\text { Pre-inquiry } \\
\quad \text { (Level 1) }\end{array}$ & $\begin{array}{c}\text { Developing } \\
\text { inquiry (Level 2) }\end{array}$ & $\begin{array}{l}\text { Proficient inquiry } \\
\text { (Level 3) }\end{array}$ & $\begin{array}{c}\text { Exemplary inquiry } \\
\text { (Level 4) }\end{array}$ \\
\hline $\begin{array}{l}\text { Order of } \\
\text { Instruction }\end{array}$ & $\begin{array}{l}\text { administrative } \\
\text { tasks, handing } \\
\text { back/collecting } \\
\text { papers, general } \\
\text { announcements, } \\
\text { time away from } \\
\text { instruction }\end{array}$ & $\begin{array}{l}\text { teacher-centred, } \\
\text { passive students, } \\
\text { prescriptive, } \\
\text { didactic } \\
\text { discourse } \\
\text { pattern, no } \\
\text { inquiry attempt }\end{array}$ & $\begin{array}{l}\text { teacher- centred } \\
\text { with some active } \\
\text { engagement } \\
\text { of students, } \\
\text { prescriptive though } \\
\text { not entirely, mostly } \\
\text { didactic with some } \\
\text { open-ended } \\
\text { discussions, teacher } \\
\text { dominates the } \\
\text { explanation, teacher } \\
\text { seen as both giver } \\
\text { of knowledge } \\
\text { and facilitator, } \\
\text { beginning of class } \\
\text { warm-ups }\end{array}$ & $\begin{array}{l}\text { largely student- } \\
\text { centred, focus on } \\
\text { students as active } \\
\text { learners, inquiries } \\
\text { are guided and } \\
\text { include students' } \\
\text { input, discourse } \\
\text { includes } \\
\text { discussions that } \\
\text { emphasize the } \\
\text { process as much as } \\
\text { the product, teacher } \\
\text { facilitates learning } \\
\text { and students } \\
\text { activity at all stages, } \\
\text { including the } \\
\text { explanation phase }\end{array}$ & $\begin{array}{l}\text { student- centred, } \\
\text { students are active } \\
\text { in constructing and } \\
\text { understanding the } \\
\text { content, rich teacher- } \\
\text { student and student- } \\
\text { student dialogues, } \\
\text { teacher } \\
\text { facilitates learning } \\
\text { in effective ways } \\
\text { to encourage } \\
\text { students' learning } \\
\text { and conceptual } \\
\text { development, } \\
\text { assumptions and } \\
\text { misconceptions are } \\
\text { challenged by students } \\
\text { and teacher }\end{array}$ \\
\hline
\end{tabular}


2008; Marshall, Horton, \& White, 2009). The instrument was designed to measure the quantity and quality of inquiry instruction being implemented and provided an adequate validity (Marshall, Smart, \& Horton, 2010). EQUIP measures 6 indicators at five-minute intervals (Activity, Organisation, Students attention to the Lesson, Cognitive, Inquiry
Instruction and Assessment) and then 19 indicators at the conclusion of the observation. The latter addresses four major constructs: Instruction, Discourse, Assessment, and Curriculum. For the analytical purposes of this paper, the Order of Instruction indicator under the Instruction construct was

Figure 3. Explanation of codes used to assess quality of inquiry (Marshall et al., 2008; Marshall, Horton, \& White, 2009).

\begin{tabular}{|l|l|}
\hline \multicolumn{1}{|c|}{ Cognitive Level-displayed by students } & \multicolumn{1}{c|}{ Components of Inquiry-facilitated by teacher } \\
\hline $\begin{array}{l}\text { 0. Other-e.g., classroom disruption, non-instructional } \\
\text { portion of lesson, administrative activity }\end{array}$ & $\begin{array}{l}\text { 0. Non-inquiry: activities with the purpose of skill } \\
\text { automation; rote memorization of facts; } \\
\text { drill and practice; checking answers on homework, quizzes, } \\
\text { or classwork with little or no explanation }\end{array}$ \\
\hline 1. Receipt of knowledge & $\begin{array}{l}\text { 1. Engage: typically situated at the beginning of the lesson; } \\
\text { assessing student prior knowledge and misconceptions; } \\
\text { stimulating student interest }\end{array}$ \\
\hline $\begin{array}{l}\text { 2. Lower order (recall, remember, understand) and/or } \\
\text { activities focused on completion exercises, computation }\end{array}$ & 2. Explore: students investigate a new idea or concept \\
\hline $\begin{array}{l}\text { 3. Apply (demonstrate, modify, compare) and/or activities } \\
\text { focused on problem solving }\end{array}$ & $\begin{array}{l}\text { 3. Explain: teacher or students making sense of an idea or } \\
\text { concept }\end{array}$ \\
\hline $\begin{array}{l}\text { 4. Analyse/Evaluate (evidence, verify, analyse, justify, } \\
\text { interpret) }\end{array}$ & $\begin{array}{l}\text { 4. Extend: students apply ideas to a new contextual setting } \\
\text { or investigate concepts in greater depth }\end{array}$ \\
\hline 5. Create (combine, construct, develop, formulate) & \\
\hline
\end{tabular}

Figure 4. Explanation of codes used to assess discourse construct (Marshall et al., 2008; Marshall, Horton, \& White, 2009).

\begin{tabular}{|l|l|l|l|l|}
\hline $\begin{array}{l}\text { Construct } \\
\text { Measured }\end{array}$ & \multicolumn{1}{c|}{$\begin{array}{c}\text { Pre-inquiry } \\
\text { (Level 1) }\end{array}$} & $\begin{array}{c}\text { Developing } \\
\text { inquiry (Level 2) }\end{array}$ & $\begin{array}{c}\text { Proficient inquiry } \\
\text { (Level 3) }\end{array}$ & $\begin{array}{c}\text { Exemplary inquiry } \\
\text { (Level 4) }\end{array}$ \\
\hline $\begin{array}{l}\text { Pattern } \\
\text { Interactions }\end{array}$ & $\begin{array}{l}\text { Communication was } \\
\text { controlled and directed } \\
\text { by teacher and followed } \\
\text { a didactic pattern }\end{array}$ & $\begin{array}{l}\text { Communication was } \\
\text { typically controlled } \\
\text { and directed by teacher } \\
\text { with occasional input } \\
\text { from other students; } \\
\text { mostly didactic pattern }\end{array}$ & $\begin{array}{l}\text { Communication was } \\
\text { often conversational } \\
\text { with some student } \\
\text { questions guiding the } \\
\text { discussion }\end{array}$ & $\begin{array}{l}\text { Communication } \\
\text { was consistently } \\
\text { conversational with } \\
\text { student questions } \\
\text { often guiding the } \\
\text { discussion }\end{array}$ \\
& $\begin{array}{l}\text { Teacher accepted } \\
\text { answers, correcting } \\
\text { when necessary, but } \\
\text { rarely followed-up with } \\
\text { further probing }\end{array}$ & $\begin{array}{l}\text { Teacher or another } \\
\text { student occasionally } \\
\text { followed-up student } \\
\text { response with further } \\
\text { low-level probe }\end{array}$ & $\begin{array}{l}\text { Teacher or another } \\
\text { student often followed- } \\
\text { up response with } \\
\text { engaging probe that } \\
\text { required student to } \\
\text { justify reasoning or } \\
\text { and effectively } \\
\text { evidence }\end{array}$ & $\begin{array}{l}\text { Teacher consilitatently rich } \\
\text { classroom dialogue } \\
\text { where evidence, } \\
\text { assumptions, and } \\
\text { reasoning were } \\
\text { challenged by teacher } \\
\text { or other students }\end{array}$ \\
\hline
\end{tabular}


used (see Figure 2) to track the progression of the instruction, followed by the Discourse construct.

As for the indicators measured at five-minute intervals, two were central to this study: Cognitive Level of students and Component of Inquiry (see Figure 3). Following the coding a rough percent of time dedicated to each category (e.g., Explore, Explain) for both of the indicators was calculated ${ }^{4}$.

Discourse construct was observed focusing on two out of five possible segments. These included communication patterns and classroom interaction pattern. Taking into account the overall organization of the lessons, the questioning levels, the complexity of the questions and the questioning ecology were excluded from the analysis (Figure 4).

\section{Results}

In both classes the organisation of the lesson unfolds in the same manner. The teacher introduces the prompts, the students spend some time working in groups, and then results are presented to the whole class. However, while the length of the lesson in one of the classes is proportional to the usual instructional time in Serbia - 45 minutes, in the other the lesson is prolonged to 60 minutes. The teacher organizes the lessons between giving a whole class instruction and working in small groups. Both lessons were systematically coded as ' $80 \%$ or more of the students are attending to the lesson' (i.e. most students are taking notes or looking at the teacher during lecture, writing on the worksheet, most students have volunteering ideas during a discussion and are engaged in small group discussions even without the presence of the teacher). In her post-lesson reflective accounts the teacher declares she was satisfied by the level of collaboration within the groups and that she noticed just a few disagreements be-

4 Observations were also coded for the Activity, Organization, Students' attention to the Lesson and Assessment order. We will briefly mention it in the results' section. tween them. She also informs that the way the lesson unfolded was fully in line with her lesson plan.

As for the time spent on different components for the order of instruction construct no differences in absolute time (counted in minutes) were found between the videotaped lessons and the non-instructional and pre-inquiry time (figure 5). Small differences are visible if we account for the proportion of time devoted to these components in reference to the full length of the lesson (45 minutes, class A; and 60 minutes, class B). Differences in both share of time and actual time devoted exist for the components developing inquiry and proficient-exemplary inquiry activities. Developing inquiry received more attention in class A, while proficient-exemplary inquiry activities received substantially more time in class B.

When the instruction provided opportunities for students to engage and explore concepts they were prompted with, a full explanation followed. Again, when students were involved in the explanation part of the lesson, these received a proficient rating or above (cf. indicators, levels 3 and/or 4, Figure 2). In both of the lessons the same observations were made and consistency in teacher practices was noted.

Following these observations, the differences between the two class groups on the percent of time devoted to different Components of Inquiry and on the Cognitive Level displayed by students were investigated as to deepen our understanding of the practices perceived on the videotaped lessons. No differences were noted between the two lessons (based on Components of Inquiry) regarding the time allocated for the Engage and Explore portions of the lesson, if we observe the actual time devoted to these activities. The time ratio in respect to the full length of the lesson does differ, but this can be attributed to the differences in the lesson length (45 vs. $60 \mathrm{~min}$ utes). The largest difference between the two observed lessons may be found in respect to the explanation portion of the lesson, $33 \%$ vs. $57 \%$ of the les- 
Figure 5. Percent of time allocated to different instructional components

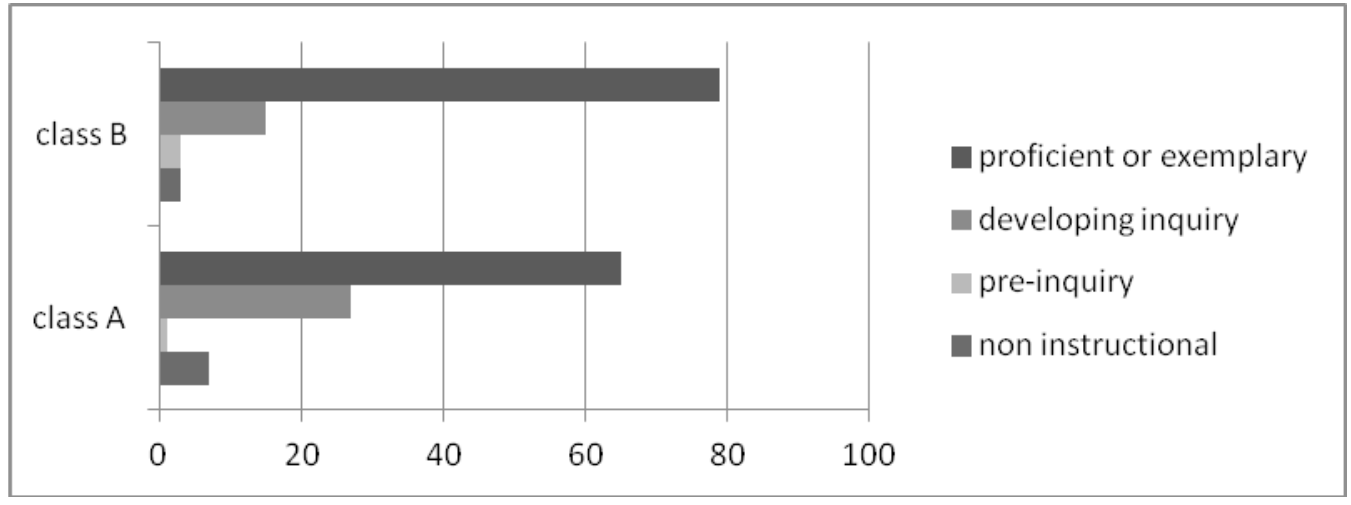

son time devoted to the activity (15 vs. 34 minutes). More time for the explanation phase was given to the students of the class B, despite the fact they have dealt with the same lesson topic and that the actual number of students does not differ between these two classes. Having in mind that this is the part of the lesson during which students are expected to actively engage in making sense of the concepts they have investigated, time allocation is equally as important as well as how that time is spent and managed by the teacher.

Cognitive Activity of Students allows for a deeper analysis of the latter aspect. The aspect was coded for all students within the class, at five-minute intervals. In both lessons less than $5 \%$ of the total lesson time was coded for cognitive level 0 referring to classroom disruption, non-instructional portion of lesson and/or administrative activity. All these speak in favour of teacher keeping track of time and how that time is used. As for the parts of the lesson devoted to engage phase (figure 6), they were consistently coded for lower levels of cognitive codes, such as recall and remember information (e.g. procedures related to transmitting lines and angles). However all these could be clearly situated only at the beginning of the lesson when the teacher is devoted to facilitating engagement of her students.

Figure 6. Percent of time allocated to different components of inquiry

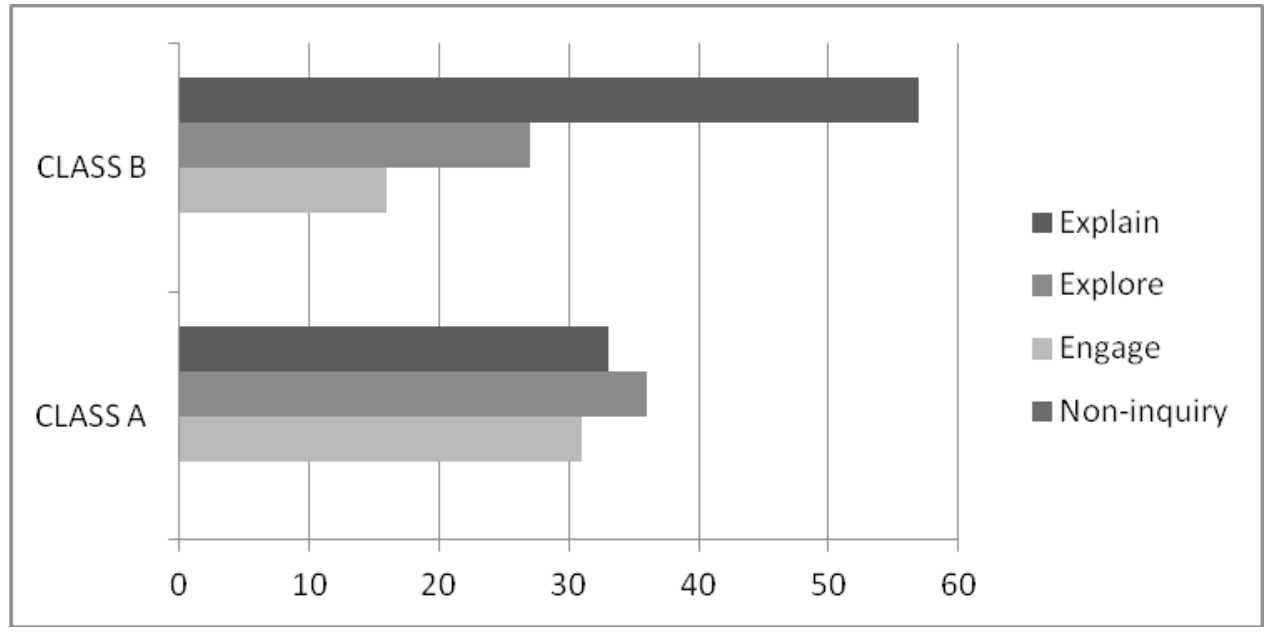


Nevertheless, already during the exploration parts of the videotaped lesson (i.e. students investigating a new idea or concept), activities were consistently coded in both classes as higher level order during which it was visible that students were focused on problem solving and combining and constructing new ideas, while the teacher was facilitating their activity. During that time the teacher was also monitoring and assessing students' progress. She was circulating around the class, probing for understanding and commenting as appropriate.

Higher level cognitive codes remained during the explain phase along with teacher's clear emphasis on students providing evidences, and to verify and justify own results. Several aspects of this part of the lesson were interesting for the focus of this study. In both lessons students were unaware of the actual time they would have for presenting their results. Even when they started exploring the concepts, no information of the given time was announced, but rather 2 minutes prior presentation teacher was announcing how much time they had left. From these actions it was clear the teacher was keeping track of time, but if we have in mind that part of the teacher's instruction related to the number of produced solutions, saying out loud how much time one has in disposal is for both the students and the teacher a useful one. For students this allows for planning of the activity within the given time constraints, while the teacher actually may be more effective in tracking how well students organize own activities.

In class B, $57 \%$ of lesson time was devoted to the Explain phase. This allowed for the groups not to be interrupted and to speak freely and without time constraints, on how they have investigated given concepts and which evidences they can provide to show that the solution they have found is the correct one. At the same time, this also allowed the teacher more time to deal with possible mistakes and misconception which may have risen in the process. We present part of the presentation given by a group in the row, during the lesson in class B (Excerpt 1).

Excerpt 1. Example of students' presentations (class B)

1. Student 1: >ok here is the first idea< (.) $\circ$ we haven't fi:nished the second one

evo ovako ovo je prva ideja (.)

-drugu nismo za:vršili。

2. Teacher: not to me sa:mo NE me:ni

3. Student 1: this is the angle (.) triangle (.) we were looking for ovo je ugao (.) trougao (.) koji smo tražili

[Turns omitted]

5. Student 1: so (.) we have transferred this line (.) that is (.) we transferred a line here (.) an arbitrary

o:vako (.) sa:da smo prvo preneli ovu duž (.) to je (.) jednu dužinu smo preneli ovde (.) proizvoljnu

6. Student 2: I mean we dra:w an arbitrary line (.) and we have measured it ((shows the prompt)) and we have tra:nsfe:rred it

mislim na:cr:tali smo proizvoljnu polupravu (.) i izmerili ovu pravu (( pokazuje na crtež)) (.) i pre:ne:li je

7. Teacher: >in< sho:rt个 (.) we have transferred a side of the train:gle (.) period $\uparrow$

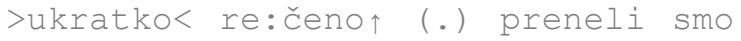
jednu stranicu tro:ugla (.) tačka

8. Student 1: then Marija transferred this o: ne angle (.) from he:re and another from he:re (.) so we e:xte:nd the $1 i$ nes and ju:st (.) and the inte:rsection point we called a T ((a boy raises his hand)) and this right where the two: met (.) we marked the thi:rd angle (.) and we have proved it by overlapping the triangle against the li:ght 
Ondaje Marija prenela ovaj je:dan

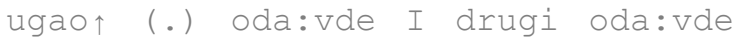
(.)pa smo pro:du:ži:li kra:ke i sa:mo (.) tačku pre:seka smo nazvali tačka T ((dečak podiže ruku)) (.) I onda tu gde su nam se srele te dve: kad su se pre:sekle (.) tu smo iznačili tre:ći ugao (.) i to smo dokazali tako što kada preklopimo na sve:tlosti budu jednake

[Turns omitted]

9. Student 1: >no no< we have this another idea we were not able to finish () (.) if we had just improved it a little bit (.) these i:de:as (.) as we all had i:de:as

>nije nije< imamo tu drugu ideju koju nismo uspeli da završimo() (.) malo da smo je samo usa:vršili (.) te i:de:je (.) jer smo svi imali i: de: je

10. Teacher: what was the be:ginning idea here?

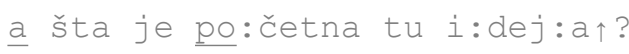

11. Student 1: we had a pro:blem in the first how to transfer the line (.) to fi:nd a way (.) then the other idea wa:s to dra:w a normal line (.) so: we didn't make it to the end (.) if we agreed among ourselves (.) we have this angle i:mali smo pro:blem da pro:nađemo na:čin u prvom kako da prenesemo liniju (.) onda druga ideja jeste bi:la da povu:čemo normalu (.) o:vaj to nismo još sti:gli (.) da smo se do:g:ovorili (.) tu imamo taj ugao

12. Student 2: triangle trougao

13. Student 1: triangle yes (.) then we wanted here to pull (.) li:ke this a norma:l line (.) and then here would normally be a $90^{\circ}$ angle (.) and the:n (.) then we could use this si:de which has these adja:cent angles (.) we could use it as the ce:ntreli:ne (.) and now a : ctually=

trougao da (.) onda smo ovde hteli da povu:čemo (.) o:vako jednu norma:lu (.)onda bi ovde normalno bio prav ugao (.) i sa:d (.) onda smo ovu stra:nicu na koju su ovi uglovi na:legli (.) mogli smo da koristimo kao sime:tra:lu (.) i sada u:stvari=

14. Teacher: =>wait wait<

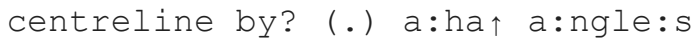
=>čekaj čekaj< simetrala čega? (.) $\mathrm{a}: \mathrm{ha} \uparrow \mathrm{uglo:va:}$

15. Student 1: yes and now (.) and here we put the divider (.) and here we ma:ke a bow (.) and then just tra:nsfer symmetrically here (.) and then when we connect we ge:t actua:lly these two e:qua:l (.) and we could prove it by overlapping it against the light on the wi:ndow da i sa:da(.) i ovde stavimo šestar (.) i tu na:pra:vimo lu:k (.) i onda samo pre:nesemo simetrično o:vde (.) i onda kada spojimo do:bijemo ustva:ri ta dva je:dna:ka (.) a to bismo mogli da dokažemo tako što bismo prislonili papir na pro:zor

In the excerpt, student 1 takes over the presentation while the second one monitors her wording. Enough time was given to them to explain what they have done and also to include the second idea they formulated with in the ongoing explanation. However, in the way they organize their wording, one can also capture who actually took part in the process of discovering possible solutions. In this case, this was a joint endeavour as the students not only systematically use the 'we' positioning, but also inform their audience when a specific move is the 
contribution of a particular group member - "then Marija transferred this o:ne angle from here and another from here so we e:xte:nd the lines and just (.) and the intersection point we called a T".

These exchanges, at the level of existing communication patterns even when the conversation is somewhat directed by the teacher, were systematically coded at levels 3 and 4 - proficient and exemplary inquiry. The exchanges take conversational, dialectical mode with students guiding the discussion, most of the time. From an interactional point of view, teacher or students often followed-up the response with engaging probe that required students to justify reasoning or evidence.

In case of the class $\mathrm{A}$, where the lesson takes the usual 45 minutes and only 15 minutes in all is given to all groups to present and explain their findings, higher cognitive levels have remained, although the exchange is more teacher-directed, thus changing to some level of existing interactional and communicational patterns. The time slot given to each group was much more restricted by the teacher, which raises the question how is then teacher able to address all the groups' misconceptions.

The teacher herself informs in her reflective accounts that she was pleased with how the lessons unfolded and that all students succeeded in resolving the assigned tasks. In her own view, each group provided at least one way concerning how to construct a triangle congruent to the given one. Some groups managed to perform all the three basic constructions of a triangle (the three side solution, two sides and the included angle solution and the two angles and included side solution). In her accounts she does not refer to the actual differences between the classes as to how much time they were then given to explain own results.

During the next lesson an individual assessment of all students was performed. The teacher concluded that all of them mastered the three-sided solution, whilst two sides and the included angle, as well as the two angles and included side so- lutions were still problematic for six students within the two classes. In the teacher's experience, this teaching unit has been a difficult one when done in a formal way during which she usually explains each of the four theorems. Only in the case of the two angles and the non-included side solution, which is not considered an intuitive solution per se, students did not offer the solution during the observed lesson but many were tempted to find it especially when at the end of the lesson; the teacher did say that there was one additional solution to the task which did not appear during the students' presentation. The teacher perceived these succeeding attempts as the direct effect of enhanced motivation and the process during which students independently come up with solutions to the given problems.

There were several specific notes on the observed lessons the researchers received from the teacher. A particularly positive one was the fact that one group of students came up with a correct, but unusual solution. They applied their knowledge from last year and transferred the given symmetric triangle in relation to an axis of symmetry. Thus, they got a congruent triangle because, as the teacher noted, "it is known that the axisymmetric triangles are congruent because they have all the same elements." The teacher perceived it as an exceptionally creative solution. She also noted that students would usually cut with scissors all the triangles they constructed and then "measure" whether these are the same or not. This was the first time they have thought to overlap the triangles against the light on the classroom window in order to check own solutions.

The difficulty the teacher refers to relates to the aspect of timing. She was aware that students had insufficient time to come up with several solutions to the given problems (Explore phase), and that, at the same moment, little time was given to analyse all the students' ideas and answers (Explain phase). However, she does not specifically tackle why she has prolonged only the lesson of the class B 
and not of the class A, and whether the actual information given to the students on how much time exactly they have for each step of the process would reduce the stress exhibited by some students. The only remark that was formulated concerning the Engage part of the lesson. The teacher declared that in the next attempts she will try to decrease time for this part of the lesson, as well as to increase the Explore section. Although the engaging portion of the lesson (Engage phase) was used for the students to recall some important aspects and procedures they need to incorporate while finding the solution, she believes that students would encounter them even on their own and this would even enhance the elicited creative aspects of the inquiry process.

\section{Discussion and conclusions}

The focus of this study was on examining of inquiry practices in mathematics through the observation of an experienced teacher in an urban school setting. More particularly, we explored the amount of time spent on various components of inquiry, the order of presentation of these components, the students' discursive patterns behind it and the relation to the cognitive students' level while performing the activities in the light of the instruction provided by the teacher.

The analysis has shown that the teacher devotes very little time to non-instructional activities, while no differences were found with respect to the pre-inquiry portion of the lesson between the two classes. Differences were found for the components developing inquiry (more time in class A) and proficient-exemplary inquiry activities (more time in the class B). With respect to the particular Components of Inquiry, no differences were found in the two classes concerning the time allocated for the Engage and Explore portions of the lesson. The largest difference between the two observed lessons was found for the Explain phase of the lesson, 33\% vs. 57\% of the lesson time devoted to the activity (minutes 15 vs. 34 minutes), for the benefit of the students of the class B. At the same time, in both lessons less than $5 \%$ of the total lesson time was coded for cognitive level 0 , referring to classroom disruption, non-instructional portion of the lesson and/or administrative activities. Sections of the lesson devoted to the Engage part were consistently coded for lower levels of cognitive codes, such as the recall and the remember information. During the Explore activities of the lesson (i.e. students investigating a new idea or concept), activities were consistently coded as higher level order during which it was observed that students were focused on problem solving, combining and constructing new ideas. Higher cognitive levels remained during the Explain phase as well.

Having in mind that among the goals of the professional development training programme, which all teachers in the school received, was to improve the quantity and quality of inquiry-based instruction implemented in the school across various subjects, the analysis showed that when instructional time included students' explorations, these were consistently associated to high Cognitive Level thinking and learning. This finding was the same regardless of the class involved. In both lessons there were very little low Cognitive Level forms of learning.

Despite the differences we found in the length of the Explain portion of the lesson, these seemed not to affect the Cognitive Level of students, despite this may have been expected. At the same time it should be noted that we have dealt here with a case study, while results of Marshal and Horton (2011) which included a larger sample of observed lessons, point exactly to that - a larger difference in the higher Cognitive Level skills such as verify, justify, develop, and formulate when more time was devoted to student exploration. However, what was noted even by the teacher in his study was the notion that little time was given for all of the phases and that when only one third of the lesson is given for the Explain 
phase alone, this may decrease opportunities for all the students' misconceptions to be tackled.

The teacher also reports to be satisfied with how the group work took place and the way students within each group have taken responsibility for the construction of knowledge. Even at the level of wording used to describe this process in the Explain phase, students would actually emphasise how they have shared the activities. Thus, although the teacher was there to monitor the process and scaffold the work when necessary, scaffolding was also visible at the peer-to-peer level. Again all these aspects contributed to the exchange to take a conversational, dialectical mode between students and students and the teacher. In particular stages, students were guiding the discussion most of the time, whereas the teacher or another student often followed-up the response with engaging probe that required student to justify reasoning or evidence, which is very much in line with the Cobb's description of inquiry in mathematics ideal (Cobb \& Yackel, 1998).

Despite the fact this was a qualitatively oriented study, we may underline a consistent relationship between the Order of Instruction that the teacher has used and the Cognitive Level at which students were engaged. When students were given an opportunity to explore the concepts prior to an explanation, they thought about the content and concepts more deeply. At the same time, they provided with a new solution to the given problem which they probably would not have reached if the lesson was organized in a more formal way (e.g. congruency of axisymmetric triangles, overlapping the triangles against the light on the classroom window to check for congruency). The teacher also informed that she was pleased with the level of acquired knowledge after the observed lessons. All these were in line with the previous findings related to application of inquiry based approach in teaching and its positive impact on student achievement and motivation (GLEF, 2001; Hmelo-Silver, Duncan \& Chinn, 2007), and development of creativity and independence of stu- dents (Kühne, 1995). Thus if creativity and critical thinking are the instructional goals, these results propose that teachers should deliberately provide opportunities for students to develop the ideas for themselves.

From the perspective of the professional development provided for the teachers it is important for them to receive a quality instruction on how to involve particular instructional moves in their own teaching, and also to receive feedback on the way they perceived the lesson did unfold (Oliveira, 2010). As per the teacher accounts in our case the time component was seen as an important obstacle in realising the lesson, while she also perceived some students to be under stress regarding whether they will complete the task on time. The teacher perceived not having sufficient time within the $45 \mathrm{~min}$ utes slot to possibly tackle all the students' misconceptions. One of the possible solutions offered for the time constraint issue, as the teacher suggested, is to decrease the engaging phase during the lesson.

However, as providers of professional development courses, we also received an important message when topic of time is included in the equation of how to conduct a quality instruction founded in inquiry approach. For the teacher trainers this means not only to train teachers on how to perform specific instructional moves, but also how to perform these within the time slots available to them, such as the 45 minutes lesson time. It is of equal importance to nurture open space for discovery within the class at the sheer level of establishing basic ground rules for activities to be performed. This means that for each step the teacher has planned to guide during the lesson time constraints need to be known by the students (e.g. you have 10 minutes to explore the prompts). In this way clear flow is maintained while lessening the stress students may experience due to the fact they do not know how much time they still have for solving the problems or exploring new solutions.

Our results are based on a limited sample that is only a case study of an experienced mathematics 
teacher in an urban elementary school with whom the researchers had been working during the previous school year. The overall goal was to improve the quantity and quality of the inquiry-based instruction being facilitated in the school through various subjects. Thus, it is to be explored whether current results hold true for other grade levels and subject areas, as well as the teachers who have not been wrapped up in an inquiry based instruction. Nonetheless, when the goal is to engage students at deeper cognitive levels, teachers may be instructed to provide sufficient time for their students to explore real-world problems prior to them (or their students) explaining the underlying concepts.

\section{References}

- Artigue, M. \& Baptist, P. (2012). Inquiry in Mathematics Education. Bruxelles: European Commission.

- Artigue, M., Dillon, J., Harlen, W., \& Léna, P. (2012). Learning Through Inquiry. Bruxelles: European Commission.

- Bakhtin, M. (1981). The dialogic imagination: Four essays by M.M. Bakhtin. Austin: University of Texas Press.

- Brousseau, G. (1997). Theory of didactical situations in mathematics. Dordrecht: Kluwer.

- Bybee, R.W., Taylor, J. A., Gardner, A., Scotter, P. V., Powell, J. C., Westbrook, A., \& Landes, N. (2006). The BSCS 5E instructional model: Origins, effectiveness, and applications. Colorado Springs: BSCSo.

- Cobb, P., \& Yackel, E. (1998). A Constructivist Perspective on the Culture of the Mathematics Classroom. In F. Seeger, J. Voigt \& U. Waschescio (Eds.), The Culture of the Mathematics Classroom (pp. 158-190). Cambridge: Cambridge University Press.

- Dewey, J. (1938). Logic: The theory of inquiry. New York: Holt.

- Eisenkraft, A. (2003). Expanding the 5E model: A proposed 7E model emphasizes "transfer of learning" and the importance of eliciting prior understanding. The Science Teacher, 70, 56-59.

- Freudenthal, H. (1973). Mathematics as an educational task. Dordrecht: Kluwer Academic Publishers.

- Friedman, T. (2005). The world is flat: A brief history of the twenty-first century. NewYork: Farrar, Straus and Giroux.

- Gašić-Pavišić, S. \& Stanković, D. (2012). Obrazovna postignuća učenika iz Srbije u istraživanju TIMSS 2011. Zbornik Instituta za pedagoška istraživnja, 44(2), 243-265.

- GLEF (George Lucas Educational Foundation). (2001). Project-based learning research. Edutopia online. [retreived 10.10.2012., URL: http://www.glef.org/php/article.php?id=Art_887]

- Hmelo-Silver, C. E. (2006). Design principles for scaffolding technologybased inquiry. In A. M. O’Donnell, C. E., Hmelo-Silver \& G. Erkens (Eds.), Collaborative reasoning, learning and technology (pp. 147-170). Mahwah: Erlbaum.

- Hmelo-Silver, C. E., Duncan, R. \& Chinn, C. A. (2007). Scaffolding and achievement in problem-based and inquiry learning: A response to Kirschner, Sweller, and Clark(2006). Educational Psychologist, 42(2), 99-107.

- Komlenović, Đ. \& Šefer, J. (Eds.). (2013). Stvaralaštvo, inicijativa i saradnja u nastavnim predmetima, III deo. Belgrade: Institut za pedagoška istraživanja. 
- Kühne, B. (1995). The Barkestorp project: Investigating school library use. School Libraries Worldwide, 1(1), $13-27$.

- Lave, J., \& Wenger, E. (1991). Situated Learning: Legitimate Peripheral Participation. Cambridge: Cambridge University Press.

- Marshall, J. C., Horton, B., Smart, J., \& Llewellyn, D. (2008). EQUIP: Electronic Quality of Inquiry Protocol. [Retrieved from Clemson University's Inquiry in Motion Institute, www.clemson.edu/iim.]

- Marshal, J. C., \& Horton, R. M. (2011). The Relationship of Teacher-Facilitated, Inquiry-Based Instruction to Student Higher-Order Thinking. School Science and Mathematics, 111(3), 93-101.

- Marshall, J. C., Horton, B., \& White, C. (2009). EQUIPping teachers: A protocol to guide and improve inquiry-based instruction. The Science Teacher, 76, 46-53.

- Marshall, J. C., Smart, J., \& Horton, R. M. (2010). The design and validation of EQUIP: An nstrument to assess inquiry-based instruction. International Journal of Science and Mathematics Education, 8, 299-321.

- Nelson, T. H. (2009). Teachers' collaborative inquiry and professional growth: Should we be optimistic? Science Education, 93(3), 548-580.

- Oliveira, A. W. (2010). Improving teacher questioning in science inquiry discussions through professional development. Journal of Research in Science Teaching, 47(4), 422-453.

- Pavlović-Babić, D., \& Baucal, A. (2013). Podrži me, Inspiriši me, PISA 2012 u Srbiji: Prvi rezultati. Belgrade: Institut za psihologiju.

- Piaget, J. (1969). Intellectual Operations and Their Development. New York: Basic Books.

- Piaget, J. \& Inhelder, B. (1978). Intelektualni razvoj deteta. Belgrade: Zavod za udžbenike i nastavna sredstva.

- Polya G. (1945, 2004). How to Solve it? New Jersey: Princeton University Press.

- PRIMAS (2011). Survey report on inquirybased learning and teaching in Europe. EuropeanComission. [available at

- http://www.primas-project.eu/servlet/supportBinaryFiles? referenceId=8\&supportId=1247]

- Quintana, C., Reiser, B. J., Davis, E. A., Krajcik, J., Fretz, E., Duncan, R. G., Kuza, E., Edelson, D., \& Soloway, E. (2004). A scaffolding design framework for software to support science inquiry. Journal of the Learning Sciences, 13, 337-386.

- Reiser, B. J. (2004). Scaffolding complex learning: The mechanisms of structuring and problematizing student work. Journal of the Learning Sciences, 13, 273-304.

- Reiser, B. J., Tabak, I., Sandoval, W. A., Smith, B. K., Steinmuller, F., \& Leone, A. J. (2001). BGuILE: Strategic and conceptual scaffolds for scientific inquiry in biology classrooms. In S. M. Carver \&D. Klahr (Eds.), Cognition and instruction: Twenty-five years of progress (pp. 263-305). Mahwah: Erlbaum.

- Rocard, M, Csermely, P., Jorde, D., Lenzen, D., Walberg-Henriksson, H., \& Hemmo, V. (2007). Scientific education now: a renewed pedagogy for the future of Europe. Bruxelles: Commission Européenne, Direction générale de la recherche, Science, économie et société.

- Rogoff, B. (1990). Apprenticeship in thinking: Cognitive development in social context. New York: Oxford University Press.

- Šefer, J., \& Radišić, J. (Eds.) (2012). Stvaralaštvo, inicijativa i saradnja, Implikacije zaobrazovnu praksu, II deo. Belgrade: Institut za pedagoška istraživanja. 
- Šefer, J., \& Ševkušić, S. (Eds.) (2012). Stvaralaštvo, inicijativa i saradnja, Novi pristup obrazovanju, I deo. Belgrade: Institut za pedagoška istraživanja.

- Šefer, J., Stanković, D., Đerić, I., \& Džinović, V. (Eds.) (2015). Pedagoški pristup Trolist:Podsticaj za stvaralaštvo, saradnjui inicijativu - Priručnik za nastavnike. Belgrade: Institut za pedagoška istraživanja, Zavod za unapređivanje obrazovanja i vaspitanja.

- Tomlinson, C. A., \& McTighe, J. (2003). Integrating differentiated instruction and understanding by design. Alexandria: Association for Supervision and Curriculum Development.

- Vygotsky, L. S. (1978). Mind in society: The development of higher psychological processes. Cambridge: Harvard University Press.

\author{
др Јелена Радишић \\ Институт за педагошка истраживања, Београд, Србија \\ мср. Смиљана Јошић \\ Институт за педагошка истраживања, Београд, Србија
}

\title{
Изазови, препреке и исходи примене истраживачког приступа у настави математике у основној школи - пример искусног наставника
}

У протекле две деценије велики значај придат је праксама поучавања које промовишу активну улогу ученика у процесу учења, те развоју критичког и дивергентног мишљења у наставном процесу. Иако је истраживачки приступ у настави потекао из наставе природних наука, током претходног периода учињени су значајни напори да му се нађе примена и у настави математике. У фокусу овог рада је испитивање пракси наставника током примене истраживачког приступа у настави математике у једној основној школи. Испитивали смо да ли се време проведено током различитих корака у истраживачком раду (представљених ученицима) и обрасци дискурса током процеса истраживања могу довести у везу са когнитивном активацијом ученика на часовима математике у два одељења у којима наставница предаје, те како наставник опажа сопствену праксу када примењује овај приступ у раду. За потребе овог истраживања снимљена су два часа математике у два одељења шестог разреда. Наставна јединица била је иста у оба одељења. Планом часа предвиђен је рад у групама, а инструкцијом се подразумевало да ученици пронађу што више начина да конструишу троугао према задатим параметрима, своју конструкцију упореде са оригиналним троуглом који су добили у листићу за рад, и да, на крају, свака група представи своја решења, уз образложење како су извршили конструкцију и доказали подударност троуглова. Оба часа анализирана су помоћу „Electronic Quality of Inquiry Protocol“ (EQUIP), креираног да прати квалитет и квантитет инструкције за време истраживачког рада. Инструмент мери шест димензија (активности, организацију, пажњу ученика, когницију, инструкцију и процену), а након посматрања је могуће описати час са преко деветнаест индикатора који се распоређују у четири конструкта - инструкција, дискурс, процена и курикулум. Индикаторни ток инструкције (когнитивни ниво и компоненте истраживачког рада) и дискурс (комуникациони 
обрасци и интеракција на часу) коришћени су за праћење напретка током часова. Када је реч о моделу поучавања у примени истраживачког рада у настави, коришћен је модел четири компоненте: укључи, истражи, објасни и прошири (engage, explore, explain i extend), са фокусом на прве три компоненте. Овај модел садржан је и у примењеном опсервационом протоколу.

Анализа је указала да наставница посвећује изузетно мало времена током часа активностима који немају везе са поучавањем (на пример, администрација), те да је највећи део часа посвећен активностима које директно укључују ученика у процес учења. У односу на референтни оквир примењених корака током истраживачког рада, нису пронађене разлике између одељења у погледу компоненти укључи и истражи. Највећа разлика уочена је током фазе часа објасни. Док је 33\% часа посвећено овој активности у једном одељењу, чак 57\% времена посвећено је истој у другом одељењу. Компоненте истражи и објасни су континуирано оцењиване високо спрам нивоа опажене когнитивне активације. То значи да су ученици активно истраживали сопствене идеје и концепте и пружали јасна објашњења, утемељена на примерима како су као група дошли до одређеног решења. Анализа комуникацијских образаца на часу подржава овај налаз. Наставница извештава да је задовољна начином на који су ученици учествовали у часу, креирали заједничко разумевање, али и стеченим знањем спрам циљева саме наставне јединице (подударност троуглова).

Даља анализа резултата стављена јеу функцију унапређења процеса професионалног усавршавања кроз које је наставница прошла заједно са колегама из школе у којој ради, с обзиром на то да је овај рад део једногодишњег процеса обучавања наставника у истој школи, а које је спроводио Институт за педагошка истраживања из Београда. Анализа појединих пракси наставника, када је конкретно реч о примени истраживачког рада у настави, указала је на потребу унапређења поменутог програма за наставнике у погледу њиховог даљег обучавања како да руководе временом на часу (оквир од четрдесет и пет минута) и омогуће квалитетно одвијање свих компоненти истраживачког рада, а нарочито оног дела који се односи на објашњења ученика.

Кључне речи: математика, истраживачки приступ у настави, наставник. 